\title{
Attitude to ICT and Self-Evaluation of Fluency in Using New Digital Devices, Websites and Software among Pre-Service Teachers
}

\author{
https://doi.org/10.3991/ijet.v15i19.16657 \\ Łukasz Tomczyk \\ Pedagogical University of Cracow, Kraków, Poland \\ lukasz.tomczyk@up.krakow.pl
}

\begin{abstract}
The objective of the research was to obtain data on the attitudes of the future generation of teachers towards using new media in their didactic and educational activities. Additionally, the text presents the level of these teachers' self-evaluation regarding the use of new ICT-based devices. Indicators of both variables are compared. The research was conducted in the biggest Polish pedagogical university, using a sample of 450 students. The technique used was the diagnostic survey. The data were collected in the first half of 2019 as part of the international project SELI. Based on the data obtained, it was noticed that pre-service teachers do not form a homogeneous group, which means there are individuals presenting a very positive attitudes towards the introduction of new media as well as those who are careful when it comes to using ICT in teaching. Most respondents emphasize that using ICT in education is necessary and that this trend is irreversible. There is a minor group of future teachers who do not know about websites and software to support learning and teaching (about 10\%). Almost half of the respondents present divided views regarding the role of ICT in stimulating engagement, motivation and interest among students. However, it should also be noted that almost half of the interviewees state that the use of smartphones at school should be banned. A positive attitude to new technologies in one area coincides with a high opinion about ICT in other areas. The self-evaluation of the teachers' own competencies is also internally coherent, meaning that respondents who declared that they had no problems with using, for example, new devices, also have no problems with using new websites or software.
\end{abstract}

Keywords-Students, pre-service teachers, ICT, Internet attitudes, new devices, Poland, SELI, media education, university, TPACK.

\section{$1 \quad$ Introduction}

The modernization of the education system in many countries must begin with an increase in the key competencies of active and pre-service teachers. Among these key competencies, skills and knowledge regarding the use of information and communication technologies (ICT) play a very significant role. This competence is increasingly 
emphasized in research reports and education development strategies in many countries. Looking at the improvement of didactic and education processes, it is important to consider the stage the information society has reached [1] [2]. Due to the development of high-speed Internet, media convergence, the transition of many activities from the offline to the online environment, the intense transformations of ICTmediated leisure activities, and the digitization of didactic processes, pre-service teacher education needs new research and solutions to improve the quality of academic training. Re-defining approaches to ICT in the preparation of future teaching staff has become the key challenge for pedagogical universities and other higher-education units. This text presents a summary report from the research on the attitudes to ICT and the level of literacy in using new digital devices, websites and software among pre-service teachers. These two variables are important components of the smart, sustainable and methodologically correct application of ICT in schools.

\section{Theoretical Framework}

Education is an area which, it would appear, does not change quickly. The introduction of new, ICT-based solutions is a noticeable exception. This results mainly from the rapid development of the information society, which is characterized by the emergence of new devices, websites and computer applications [3]. The ability to recognize and introduce these solutions into teaching processes is considered as one of the key competencies of teachers. When analyzing the issues surrounding the computerization of modern schools, one should consider the fact that teachers are a heterogeneous group and present different levels of digital literacy [4]. This diversity is not determined simply by socio-demographic features or teaching specialization in certain subjects (for example, it is obvious that IT and computer teachers naturally use ICT more) but also results from the educational policies implemented in certain countries. However, researchers point out that one of the critical factors in the implementation of ICT is the ability to experiment with new technologies [5] [6] [7]. Individual preferences and overcoming resistance to new, ICT-based solutions have a significant impact on the modernization of the education system, increasing the attractiveness of classes and strengthening learners' motivation [8] [9]. Consequently, this text is an attempt to show how pre-service teachers, classified as digital natives (the generation that grew up in the information society), use new technologies.

Of the various concepts that describe the knowledge, skills, and attitudes connected with new media among teachers, the most prominent is TPACK. It assumes that the effective use of ICT depends on knowledge of technology - digital literacy, knowledge about the given area - and subject and pedagogical competencies. When integrated, these three areas create an ecosystem which facilitates the proper realization of the didactic and education processes. The lack of such integration leads to the failure to meet operational goals [10] [11] [12] [13]. Of course, the presented theoretical framework has some gaps. One of the main ones is the difficulty of transferring beliefs into practice [14]. The TPACK concept also identifies a variable related to attitude - the attitude towards new technologies. Attitudes are variable and not fixed 
and vary depending on the development of digital literacy and changes in the digital world [15] [16] [17]. In the debate on introducing digital media into education, attitudes toward ICT become the starting point in regard to the preparation of the future generations of teachers [18]. Both variables mentioned above have become the main focus of the analyses of students of pedagogy who will soon have the opportunity to start their careers in the education sector.

\section{$3 \quad$ Methodology}

\subsection{Research objective and problems}

The objective of the research was to investigate the attitudes of the future generation of teachers towards using new media in their didactic and educational activities. Another goal was to obtain the results of self-evaluation of the ease of use of new websites, devices and applications among students of pedagogical studies. The research is diagnostic and classified as studies into the basic problems of media pedagogy. The research objective was motivated by the need to diagnose the components of digital literacy and individual and environmental conditions of the future generation of teachers. The study is embedded in the opportunity's paradigm of media pedagogy; that is, the positive opportunities connected with the implementation of new media in education [19]. The research was part of the international project Smart Ecosystem for Learning and Inclusion - SELI ERANet17/ICT-0076, financed by the National Centre for Research and Development [20]. The following problems were formulated:

- What is the attitude to new media among pre-service teachers?

- What are the relationships between certain elements of that attitude to new media among students of pedagogical specializations?

- How do pedagogy students evaluate their own skills in terms of the ease of use of new devices, websites and software?

- What is the strength of correlation between the ease of using new websites, software, and computer applications?

- To what extent does the self-evaluation of digital literacy coexist with the selfevaluation of fluency in using new ICTs?

- Which elements of the attitude to new media determine the level of satisfaction in using the new technologies?

\subsection{Research tool}

The research tool was designed by the international team of researchers engaged in the SELI project. It was subject to a pilot study in Poland and eight other countries in Latin America, the Caribbean and Europe. Two variables are mentioned in the text:

- Attitude to new media. The tool shows high internal coherence - McDonald's $\omega=$ 0.849 ; Cronbach's $\alpha=0.822$; Gutmann's $\lambda 6=0.853$. The variable has 9 indicators 
of evaluation of using new media in didactic and educational work. The tool was created based on the previous research conducted by the author [21].

- The perception of ease of use of ICT consists of four indicators which determine the subjective feeling regarding the use of new technologies. One of the indicators describes general satisfaction from using new technologies. The whole variable has good internal coherence - McDonald's $\omega=0.860$; Cronbach's $\alpha=0.849$; Gutmann's $\lambda 6=0.830[22][23]$.

\subsection{Sample and research procedure}

The research was conducted among the students of pedagogical courses in the biggest Polish pedagogical university. The technique used was the diagnostic survey which was conducted among 450 students of the Faculty of Pedagogy, the Pedagogical University of Krakow in Poland. The study was carried out in May-June 2019. The average age of the students was 22.66, with a standard deviation of 4.23. The research was conducted according to ethical standards. Participation in the survey was voluntary. The data do not enable the identification of individual respondents. The research enables the generalization of the results only in regard to the population of students of the Pedagogical University (Faculty of Pedagogy). We wish to thank the financing institution: The National Centre for Research and Development (NCBiR, Narodowe Centrum Badań i Rozwoju), the interviewers: Dr Joanna Wnęk-Gozdek and Dr Anna Mróz and the teams from nine countries who contributed to the development of the tool [24].

\section{$4 \quad$ Results}

As discussed in the theoretical section of this paper, it is the subjective perception of new media that is one of the main factors determining the correct implementation of new technologies in education, learning and teaching processes. Tables 1 and 2 present the descriptive statistics for nine variables which are the factors selected to characterize the attitude of students to using ICT in schools. Based on the data collected, it can be noticed that prospective teachers have diverse opinions about the influence of new technologies. Almost half of them think that ICT brings positive changes into our lives. Almost two-thirds of the pedagogy students interviewed state there is no way back (to pre-digital times) and that the use of ICT in didactic work is necessary. Only one in ten students declare that they did not know any websites that can be helpful in teaching. It is interesting that this young generation of teachers are not extreme techno-optimists. This is visible in the diverse opinions they share as they compare "old" and "new" didactic methods. About a quarter of the respondents emphasize the point that ICT is better than the analogue equivalents. Almost $40 \%$ of the young people have divided opinions regarding the positive impact of ICT on learning. 
Table 1. Descriptive statistics for variable Attitude to new media - Part I

\begin{tabular}{|l|c|c|c|c|c|}
\hline & $\begin{array}{c}\text { Digital } \\
\text { technologies } \\
\text { have positively } \\
\text { changed our } \\
\text { lives }\end{array}$ & $\begin{array}{c}\text { It is necessary to use } \\
\text { digital technologies } \\
\text { in the process of } \\
\text { learning and } \\
\text { teaching }\end{array}$ & $\begin{array}{c}\text { Web sites are } \\
\text { useful for } \\
\text { teaching and } \\
\text { learning }\end{array}$ & $\begin{array}{c}\text { Digital teaching } \\
\text { aids are better } \\
\text { than physical } \\
\text { teaching aids on } \\
\text { improving } \\
\text { learning }\end{array}$ & $\begin{array}{c}\text { The use of digital } \\
\text { technologies by } \\
\text { the teacher has a } \\
\text { positive impact } \\
\text { on student } \\
\text { learning }\end{array}$ \\
\hline Valid & 450 & 450 & 450 & 450 & 450 \\
\hline Mean & 3.571 & 3.727 & 3.811 & 2.976 & 3.402 \\
\hline Median & 4.000 & 4.000 & 4.000 & 3.000 & 3.000 \\
\hline Mode & 4.000 & 4.000 & 4.000 & 3.000 & 3.000 \\
\hline Std. Deviation & 0.930 & 0.912 & 0.916 & 0.942 & 0.935 \\
\hline Variance & 0.865 & 0.832 & 0.840 & 0.888 & 0.873 \\
\hline Skewness & -0.601 & -0.955 & -1.170 & 0.161 & -0.503 \\
\hline Kurtosis & 0.400 & 0.829 & 1.501 & -0.045 & 0.304 \\
\hline Shapiro-Wilk & 0.872 & 0.817 & 0.788 & 0.894 & 0.878 \\
\hline $\begin{array}{l}\text { P-value of } \\
\text { Shapiro-Wilk }\end{array}$ & $<.001$ & $<.001$ & $<.001$ & $<.001$ & $<.001$ \\
\hline
\end{tabular}

The prospective teachers recognize the potential of new media. Almost half of them declare that they definitely agree or agree with the statement that using ICT in school has a positive impact on students' motivation and engagement. Only about $14 \%$ suggest that the teacher's use of ICT does not have a positive influence on satisfaction from learning. It is interesting to compare these data with the opinions about using smartphones in schools. Almost half of the respondents' state that the use of smartphones at school should be prohibited, which is contrary to their previous declarations.

Table 2. Descriptive statistics for variable Attitude to new media - Part II

\begin{tabular}{|l|c|c|c|c|}
\hline & $\begin{array}{c}\text { The use of digital } \\
\text { technologies by the } \\
\text { teacher has a } \\
\text { positive effect on } \\
\text { student motivation }\end{array}$ & $\begin{array}{c}\text { The use of digital } \\
\text { technologies by the } \\
\text { teacher has a } \\
\text { positive effect on } \\
\text { student involve- } \\
\text { ment }\end{array}$ & $\begin{array}{c}\text { The use of digital } \\
\text { technologies by the } \\
\text { teacher has a } \\
\text { positive effect on } \\
\text { student satisfaction }\end{array}$ & $\begin{array}{c}\text { Students should be } \\
\text { prohibited from } \\
\text { using cell phones at } \\
\text { school }\end{array}$ \\
\hline Valid & 450 & 450 & 450 & 450 \\
\hline Mean & 3.367 & 3.458 & 3.493 & 3.356 \\
\hline Median & 3.000 & 4.000 & 4.000 & 3.000 \\
\hline Mode & 4.000 & 4.000 & 4.000 & 4.000 \\
\hline Std. Deviation & 0.975 & 0.981 & 0.947 & 1.187 \\
\hline Variance & 0.950 & 0.961 & 0.896 & 1.410 \\
\hline Skewness & -0.426 & -0.479 & -0.463 & -0.363 \\
\hline Kurtosis & -0.205 & -0.214 & -0.042 & -0.690 \\
\hline Shapiro-Wilk & 0.891 & 0.886 & 0.886 & 0.903 \\
\hline $\begin{array}{l}\text { P-value of Shapiro- } \\
\text { Wilk }\end{array}$ & $<.001$ & $<.001$ & $<.001$ & $<.001$ \\
\hline
\end{tabular}

Given the non-parametric distribution of factors, the co-existence of answers was calculated using Spearman's rho correlation coefficient. The data collected enabled 
several important conclusions to be drawn. First, a positive attitude to new media in one area co-exists in other areas. Second, save for a few exceptions related to motivation, engagement and satisfaction, the strength of correlations does not exceed the mean values. Third, the pre-service teachers who stated that smartphones should be banned at school are not, however, techno-pessimists. Thus, there is no linear correlation between the attitude to new media and the opinion held about using phones at school. The details about the strength of correlations for the attitude to new media factors is presented in Table 3 .

Table 3. Spearman's rho correlation coefficient for indicators of variable Attitude to new media

\begin{tabular}{|c|c|c|c|c|c|c|c|c|}
\hline Variable & 1 & 2 & 3 & 4 & 5 & 6 & 7 & 8 \\
\hline $\begin{array}{l}\text { 1. Digital technologies } \\
\text { have positively changed } \\
\text { our lives }\end{array}$ & - & & & & & & & \\
\hline $\begin{array}{l}\text { 2. It is necessary to use } \\
\text { digital technologies in } \\
\text { the process of learning } \\
\text { and teaching }\end{array}$ & $0.443 * * *$ & - & & & & & & \\
\hline $\begin{array}{l}\text { 3. Web sites are useful } \\
\text { for teaching and learn- } \\
\text { ing }\end{array}$ & $0.332 * * *$ & $0.340 * * *$ & - & & & & & \\
\hline $\begin{array}{l}\text { 4. Digital teaching aids } \\
\text { are better than physical } \\
\text { teaching aids on im- } \\
\text { proving learning }\end{array}$ & $0.390 * * *$ & $0.403 * * *$ & $0.331 * * *$ & - & & & & \\
\hline $\begin{array}{l}\text { 5. The use of digital } \\
\text { technologies by the } \\
\text { teacher has a positive } \\
\text { impact on student } \\
\text { learning }\end{array}$ & $0.489 * * *$ & $0.508 * * *$ & $0.350 * * *$ & $0.495 * * *$ & - & & & \\
\hline $\begin{array}{l}\text { 6. The use of digital } \\
\text { technologies by the } \\
\text { teacher has a positive } \\
\text { effect on student moti- } \\
\text { vation }\end{array}$ & $0.365 * * *$ & $0.329 * * *$ & 0.280 *** & $0.348 * * *$ & $0.571 * * *$ & 一 & & \\
\hline $\begin{array}{l}\text { 7. The use of digital } \\
\text { technologies by the } \\
\text { teacher has a positive } \\
\text { effect on student in- } \\
\text { volvement }\end{array}$ & $0.320 * * *$ & $0.356 * * *$ & $0.254 * * *$ & $0.342 * * *$ & $0.486^{* * * *}$ & $0.716^{* * * *}$ & - & \\
\hline $\begin{array}{l}\text { 8. The use of digital } \\
\text { technologies by the } \\
\text { teacher has a positive } \\
\text { effect on student satis- } \\
\text { faction }\end{array}$ & $0.348 * * *$ & $0.311 * * *$ & $0.203 * * *$ & $0.350 * * *$ & $0.474 * * *$ & $0.655 * * *$ & $0.700 * * *$ & - \\
\hline $\begin{array}{l}\text { 9. Students should be } \\
\text { prohibited from using } \\
\text { cell phones at school }\end{array}$ & $0.110 *$ & $0.115^{*}$ & 0.008 & 0.002 & 0.115 & 0.045 & 0.057 & 0.026 \\
\hline
\end{tabular}

$* \mathrm{p}<.05, * * \mathrm{p}<.01, * * * \mathrm{p}<.001$ 
The vast majority $(85.5 \%)$ of pre-service teachers declare that they like using new technologies. Almost two-thirds of the respondents (60.9\%) emphasize that they find using new software easy or very easy. Slightly more than three-quarters of the students declare that they have no problems with using new websites. In turn, $62.4 \%$ think they will be able to operate new devices at a satisfactory or very high level. Thus, the respondents' perception of their own digital literacy in terms of using new devices and software is very high. They are, therefore, a typical example of a generation that grew up in the information society. The details regarding the indicators are presented in Table 4.

Table 4. Descriptive statistics for variable Perception of easy use of ICT

\begin{tabular}{|l|c|c|c|c|}
\hline & $\begin{array}{c}\text { I like to use digital } \\
\text { technologies }\end{array}$ & $\begin{array}{c}\text { Using a new soft- } \\
\text { ware is easy for me }\end{array}$ & $\begin{array}{c}\text { Using a new web- } \\
\text { site is easy for me }\end{array}$ & $\begin{array}{c}\text { Using a new elec- } \\
\text { tronic device is easy } \\
\text { for me }\end{array}$ \\
\hline Valid & 450 & 450 & 450 & 450 \\
\hline Mean & 4.087 & 3.544 & 3.829 & 3.571 \\
\hline Median & 4.000 & 4.000 & 4.000 & 4.000 \\
\hline Mode & 4.000 & 4.000 & 4.000 & 4.000 \\
\hline Std. Deviation & 0.955 & 1.065 & 0.996 & 1.097 \\
\hline Variance & 0.912 & 1.135 & 0.993 & 1.203 \\
\hline Skewness & -1.560 & -0.611 & -1.117 & -0.716 \\
\hline Kurtosis & 2.787 & -0.294 & 1.143 & -0.128 \\
\hline Shapiro-Wilk & 0.743 & 0.876 & 0.813 & 0.868 \\
\hline $\begin{array}{l}\text { P-value of } \\
\text { Shapiro-Wilk }\end{array}$ & $<.001$ & $<.001$ & $<.001$ & $<.001$ \\
\hline
\end{tabular}

An attempt was made to evaluate certain components of digital literacy. For this purpose, the two indicators connected with the use of new technology solutions and the self-evaluation of digital literacy in the use of elements of the office package were selected. The variables are compared in Fig. 1. It can be noted that individuals who evaluate their own competencies in using the office package as high, also highly regard their skills in using devices and websites. This correlation is linear with one exception. The students who declare they have problems with the office package are also those who, in general, like or very much like using new technologies. At the same time, it should be emphasized that respondents who perceive their own digital literacy in using office packages as low gave the most diverse answers. This group is highly heterogeneous. 


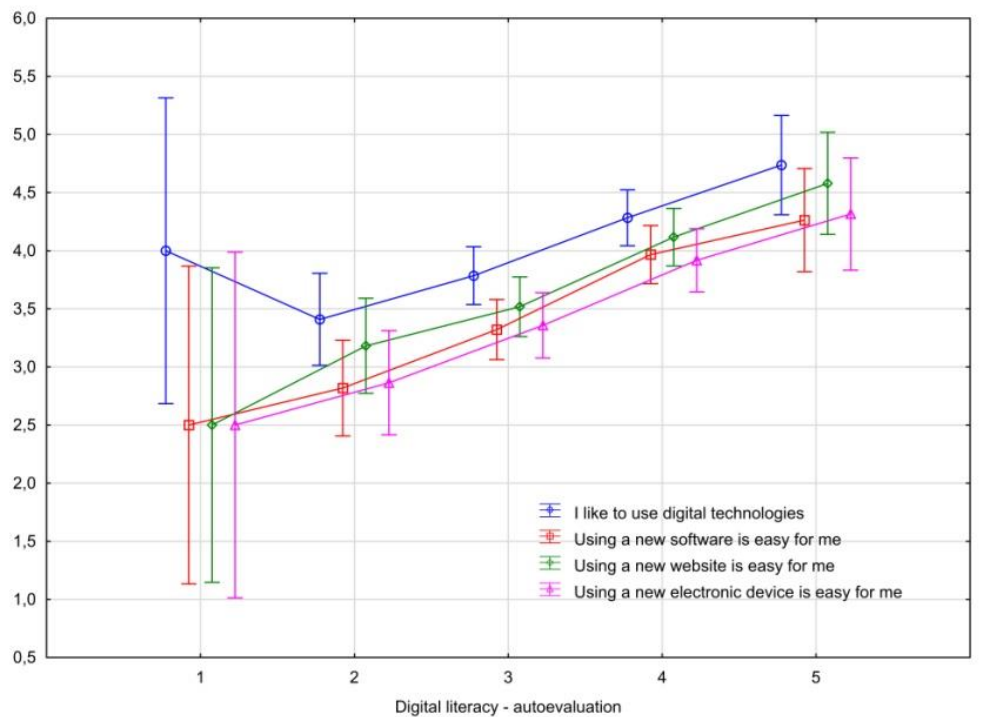

Fig. 1. Comparison of self-evaluation of digital literacy and perception of easy use of ICT

The students declaring that using new technologies is easy are very consistent in their declarations. It can be noted that individuals who state that using one type of ICT-based solutions is very easy for them, give similar declarations regarding other areas. Thus, one can speak of an internal coherence in the self-evaluation of using new devices. The details about the correlations are presented in Table 5.

Table 5. Spearman's rho correlation coefficient for indicators of perception of easy use of ICT

\begin{tabular}{|l|c|c|c|}
\hline & $\mathbf{1}$ & $\mathbf{2}$ & $\mathbf{3}$ \\
\hline 1. I like to use digital technologies & - & & \\
\hline 2. Using a new software is easy for me & $0.348^{* * *}$ & - & \\
\hline 3. Using a new website is easy for me & $0.321^{* * *}$ & $0.717^{* * *}$ & - \\
\hline 4. Using a new electronic device is easy for me & $0.343^{* * *}$ & $0.747^{* * *}$ & $0.772^{* * *}$ \\
\hline
\end{tabular}

$* \mathrm{p}<.05, * * \mathrm{p}<.01, * * * \mathrm{p}<.001$

Considering the model approach to the indicator I like to use digital technologies, it was noticed that when the multi-linear regression analysis is used, only two factors of the proposed model are in relation with the dependent variable. Given the assumption adopted which explains $37.9 \%$ of cases, the growth of the I like to use new technologies indicator is in positive correlation with the first three indicators. The first three indicators (digital technologies have positively changed our lives; it is necessary to use digital technologies in the process of learning and teaching; web sites are useful for teaching and learning) are not directly connected with the individual didactic aspects (as opposed to the others, which are not statistically significant). The variables that are related are connected with general assumptions of digitally mediated pedagogy rather than with specific elements of didactics. 
Table 6. Multilinear regression analysis - dependent variable: I like to use digital technologies

\begin{tabular}{|l|c|c|c|c|c|c|c|}
\hline \multirow{2}{*}{$\mathbf{N}=\mathbf{4 5 0}$} & \multicolumn{6}{|c|}{$\begin{array}{l}\text { Dependent variable: I like to use digital R= 0.616 } \\
\mathbf{R 2}=\mathbf{0 . 3 7 9} \mathbf{R 2}=\mathbf{0 . 3 6 7} \mathbf{F}(\mathbf{9 , 4 4 0}) \mathbf{2 9 . 9 5 6} \mathbf{p}<\mathbf{0 . 0 0 0}\end{array}$} \\
\cline { 2 - 8 } & $\boldsymbol{\beta}$ & $\boldsymbol{S E}$ & $\boldsymbol{b}$ & $\boldsymbol{S E}$ & $\boldsymbol{t}(\mathbf{4 4 0})$ & $\boldsymbol{p}$ \\
\hline Intercept & & & 0.985 & 0.222 & 4.437 & 0 \\
\hline $\begin{array}{l}\text { 1. Digital technologies have positively changed our } \\
\text { lives }\end{array}$ & 0.27 & 0.049 & 0.278 & 0.05 & 5.548 & 0 \\
\hline $\begin{array}{l}\text { 2. It is necessary to use digital technologies in the } \\
\text { process of learning and teaching }\end{array}$ & 0.187 & 0.048 & 0.196 & 0.05 & 3.896 & 0 \\
\hline 3. Web sites are useful for teaching and learning & 0.247 & 0.044 & 0.257 & 0.046 & 5.609 & 0 \\
\hline $\begin{array}{l}\text { 4. Digital teaching aids are better than physical teach- } \\
\text { ing aids on improving learning }\end{array}$ & 0.01 & 0.047 & 0.01 & 0.047 & 0.222 & 0.825 \\
\hline $\begin{array}{l}\text { 5. The use of digital technologies by the teacher has a } \\
\text { positive impact on student learning }\end{array}$ & -0.015 & 0.057 & -0.016 & 0.058 & -0.272 & 0.785 \\
\hline $\begin{array}{l}\text { 6. The use of digital technologies by the teacher has a } \\
\text { positive effect on student motivation }\end{array}$ & 0.081 & 0.062 & 0.08 & 0.061 & 1.317 & 0.189 \\
\hline $\begin{array}{l}\text { 7. The use of digital technologies by the teacher has a } \\
\text { positive effect on student involvement }\end{array}$ & -0.047 & 0.064 & -0.046 & 0.062 & -0.732 & 0.465 \\
\hline $\begin{array}{l}\text { 8. The use of digital technologies by the teacher has a } \\
\text { positive effect on student satisfaction }\end{array}$ & 0.083 & 0.058 & 0.084 & 0.058 & 1.437 & 0.151 \\
\hline $\begin{array}{l}\text { 9. Students should be prohibited from using cell } \\
\text { phones at school }\end{array}$ & 0.007 & 0.038 & 0.005 & 0.031 & 0.173 & 0.863 \\
\hline
\end{tabular}

\section{Discussion}

The digital school is a relevant and important issue. The importance of the implementation of digital media in didactics and educational activities is noticeable in both the scientific discourse and in more general debates. The use of ICT has become even more significant in these times of the COVID-19 pandemic [19]. It has forced stakeholders to acknowledge how important it is to equip teachers and students with those competencies that facilitate their access to digital learning and teaching ecosystems [24]. In an age of intense changes caused by computerization, present and prospective teachers face many challenges regarding the use of new media. The above-mentioned factors raise many questions too. The areas of self-evaluation of digital literacy and attitude to new media presented herein are one such element.

Referring to the data collected, it is clear that the future generation of teachers is not fully united in their opinions that new technologies bring with them only positive changes. Their opinions are divided. Thus, declaring that digital natives (the sample representatives) agree fully that ICT should be considered only in the light of opportunities for development is not true. Some representatives of digital immigrants share similar concerns as digital natives [25] [26]. This also sheds new light on the still extant and artificial division of teachers into those from the pre-digital era and those who grew up and are growing up in the information society. It is also interesting that, despite recognizing the potential of new media, about half of the pre-service teachers declare that the use of smartphones should be prohibited during school education. This causes some cognitive dissonance, as the new generation denies some attributes assigned to their age group. A ban on smartphones is problematic and has not been 
solved by researchers, methodology experts, teachers, parents or public opinion [27] [28] [29].

Nevertheless, two thirds of the respondents point out that using new media stimulates students' engagement, motivation and make them see classes as more attractive. These answers provide some guidance for modernization but it must be mentioned that about $30 \%$ of the respondents hold a completely different opinion on this matter. These persons (about 30\%) are classified as techno-pessimists or techno-ignorant, who do not believe in the positive impact of all or some new technologies on education. They are pre-service teachers who appreciate the role of "traditional" (i.e. analogue) didactic means [30] [31] [32]. A positive attitude in one area describing ICT in education is strongly correlated with other areas. Consequently, the group of technooptimists is internally coherent. These persons may prove particularly valuable in the process of school modernization which can be implemented through the efforts of the young teachers.

\section{Conclusion}

The research presented sheds an interesting light on the changes to the education system and the training of pre-service teacher training. The future of education depends largely not only on political changes and further equipping schools with digital solutions but also on competencies, skills, knowledge and attitudes. These last factors are especially important as the generations change. In many schools, new teachers can be and are those who transform the methods of working with students, through the implementation of ICT as well as by other means. However, it must be recognized that the preparation of teachers is, to a large extent, the responsibility of the institutions that provide teacher training. High self-evaluation of digital literacy and relatively positive attitude to new media should be complemented with the knowledge of methodology and digital literacy regarding the educational aspects of using new digital devices and software. This means that the academic courses must be improved. In the age of the rapid development of the information society, the process of changes is never-ending. The permanent nature of changes and life-long learning are the variables which should be included in the new research models and education policies at lower (e.g. university) levels.

\section{$7 \quad$ Acknowledgement}

This work was supported by the ERANET-LAC project which has received funding from the European Union Seventh Framework Programme. Project Smart Ecosystem for Learning and Inclusion - ERANet17/ICT-0076SELI. In Poland the project was supported by the National Centre for Research and Development (NCBiR). 


\section{$8 \quad$ References}

[1] Wątróbski, J., Ziemba, E., Karczmarczyk, A., \& Jankowski, J. (2018). An Index to Measure the Sustainable Information Society: The Polish Households Case. Sustainability, 10(9), 3223. https://doi.org/10.3390/su10093223

[2] Ziemba, E. (2017). The Contribution of ICT Adoption to the Sustainable Information Society. Journal of Computer Information Systems, 59(2), 116-126. https://doi.org/10.10 $\underline{\text { 80/08874417.2017.1312635 }}$

[3] Eger, L. (2015). Is Facebook a similar learning tool for university students as LMS?. Procedia-Social and Behavioral Sciences, 203, 233-238. https://doi.org/10.1016/j.sbspro. $\underline{2015.08 .287}$

[4] Tomczyk, Ł. (2020). Skills in the area of digital safety as a key component of digital literacy among teachers. Education and Information Technologies, 25(1), 471-486. https:// doi.org/10.1007/s10639-019-09980-6

[5] Stosic, L. (2015). The importance of educational technology in teaching. International Journal of Cognitive Research in Science, Engineering and Education, 3(1).

[6] Monacis, L., Ceglie, F., Limone, P., Tanucci, G., \& Sinatra, M. (2019). EXPLORING INDIVIDUAL DIFFERENCES AMONG TEACHERS'ICT ACCEPTANCE: A PATH MODEL AND THE ROLE OF EXPERIENCE. Human Technology, 15(2). https://doi.org/ 10.17011/ht/urn.201906123159

[7] Istenič Starčič, A., \& Lebeničnik, M. (2020). Investigation of University Students’ Perceptions of Their Educators as Role Models and Designers of Digitalized Curricula. Human Technology, 16(1), 55-91. https://doi.org/10.17011/ht/urn.202002242163

[8] Aesaert, K., van Braak, J., Van Nijlen, D., \& Vanderlinde, R. (2015). Primary school pupils' ICT competences: Extensive model and scale development. Computers \& Education, 81, 326-344. https://doi.org/10.1016/j.compedu.2014.10.021

[9] Vodopivec, J. L., \& Bagon, S. (2016). Motivation for using ICT and pupils with learning difficulties. International Journal of Emerging Technologies in Learning (iJET), 11(10), 70-75. https://doi.org/10.3991/ijet.v11i10.5786

[10] Andyani, H., Setyosari, P., Wiyono, B. B., \& Djatmika, E. T. (2020). Does Technological Pedagogical Content Knowledge Impact on the Use of ICT In Pedagogy? International Journal of Emerging Technologies in Learning (iJET), 15(03), 126. https://doi.org/10. 3991/ijet.v15i03.11690

[11] Şenel, E., \& Nazlı, S. Y. (2016). Preservice preschool teacher's self-efficacy beliefs and attitudes toward teaching profession. Educational Research and Reviews, 11(7), 345-357. https://doi.org/10.5897/err2016.2648

[12] Elas, N., Majid, F., \& Narasuman, S. (2019). Development of Technological Pedagogical Content Knowledge (TPACK) For English Teachers: The Validity and Reliability. International Journal Of Emerging Technologies In Learning (IJET), 14(20), pp. 18-33. https://doi.org/10.3991/ijet.v14i20.11456

[13] Mulyadi, D., Wijayatingsih, T. D., Budiastuti, R. E., Ifadah, M., \& Aimah, S. (2020). Technological Pedagogical and Content Knowledge of ESP Teachers in Blended Learning Format. International Journal of Emerging Technologies in Learning (iJET), 15(06), 124. https://doi.org/10.3991/ijet.v15i06.11490

[14] Kabakci Yurdakul, I., \& Coklar, A. N. (2014). Modeling preservice teachers' TPACK competencies based on ICT usage. Journal of Computer Assisted Learning, 30(4), 363376. https://doi.org/10.1111/jcal.12049

[15] Novković Cvetković, B., Stošić, L., \& Belousova, A. (2018). Media and Information Literacy-the Basis for Applying Digital Technologies in Teaching from the Discourse of Edu- 
cational Needs of Teachers. Croatian Journal of Education: Hrvatski časopis za odgoj $i$ obrazovanje, 20(4), 1089-1114. https://doi.org/10.15516/cje.v20i4.3001

[16] Stošić, L., \& Stošić, I. (2015). Perceptions of teachers regarding the implementation of the internet in education. Computers in Human Behavior, 53, 462-468. https://doi.org/10.1016/ j.chb.2015.07.027

[17] Uluyol, Ç., \& Şahin, S. (2016). Elementary school teachers' ICT use in the classroom and their motivators for using ICT. British Journal of Educational Technology, 47(1), 65-75. https://doi.org/10.1111/bjet.12220

[18] Eger, L., Klement, M., Tomczyk, Ł., Pisoňová, M., \& Petrová, G. (2018). Different user groups of university students and their ICT competence: evidence from three countries in Central Europe. Journal of Baltic Science Education, Journal of Baltic Science Education, 17(5). https://doi.org/10.33225/jbse/18.17.851

[19] Pyżalski, J. (red.) (2020). Edukacja w czasach pandemii wirusa COVID-19. Z dystansem o tym, co robimy obecnie jako nauczyciele. Warszawa: EduAkcja.

[20] Tomczyk, Ł., \& Sunday Oyelere, S. (2019). ICT for Learning and Inclusion in Latin America and Europe. Case Study from Countries: Bolivia, Brazil, Cuba, Dominican Republic, Ecuador, Finland, Poland, Turkey, Uruguay. Cracow: Pedagogical University of Cracow. https://doi.org/10.24917/9788395373732.7

[21] Tomczyk, Ł., Szotkowski, R., Fabiś, A., Wąsiński, A., Chudý, Š., \& Neumeister, P. (2017). Selected aspects of conditions in the use of new media as an important part of the training of teachers in the Czech Republic and Poland - differences, risks and threats. Education and Information Technologies, 22(3), 747-767. https://doi.org/10.1007/s10639-0159455-8

[22] Taubert, M. (2006). European Computer Driving Licence (ECDL). BMJ, 332(7540), s89.1-s89. https://doi.org/10.1136/bmj.332.7540.s89

[23] Petuhova, L. E., Osipova, N. V., \& Kushnir, N. O. (2010). Actual Problems Of Implementing Ecdl Course In The Training Of Teachers. Information Technologies in Education, (8), 17-22. https://doi.org/10.14308/ite000198

[24] Tomczyk, L., Oyelere, S. S., Amato, C., Martins, V. F., Motz, R., Barros, G., ... \& Muñoz, D. (2020). Smart Ecosystem for Learning and Inclusion-assumptions, actions and challenges in the implementation of an international educational project. In Adult Education 2019-in the Context of Professional Development and Social Capital. Proceedings of the 9th International Adult Education Conference. Prague: Czech Andragogy Society.

[25] Teo, T. (2013). Digital nativity: A definitional framework. World Journal on Educational Technology, 5(3), 389-394.

[26] Marshall, S. J. (2018). Technology and Modern Students—The Digital Natives Fallacy. In Shaping the University of the Future (pp. 197-211). Springer, Singapore. https://doi.org/10. 1007/978-981-10-7620-6_10

[27] Norris, C., Hossain, A., \& Soloway, E. (2011). Using smartphones as essential tools for learning: A call to place schools on the right side of the 21st century. Educational Technology, 18-25.

[28] Seifert, T. (2018, March). Smartphone implementation from lecturers, teachers, students and pupils' perspectives. In Society for Information Technology \& Teacher Education International Conference (pp. 795-801). Association for the Advancement of Computing in Education (AACE).

[29] Machmud, K. (2018). The smartphone use in Indonesian schools: the high school students' perspectives. Journal of Arts and Humanities, 7(3), 33-40. https://doi.org/10.18533/journ al.v7i3.1354 
[30] Krumsvik, R. J. (2008). Situated learning and teachers' digital competence. Education and Information Technologies, 13(4), 279-290. https://doi.org/10.1007/s10639-008-9069-5

[31] Fedeli, L. (2017). School, curriculum and technology: what and how of their connections. Education Sciences \& Society-Open Access Journal, 8(2).

[32] Motschnig-Pitrik, R., \& Holzinger, A. (2002). Student-centered teaching meets new media: Concept and case study. Journal of Educational Technology \& Society, 5(4), 160-172.

\section{$9 \quad$ Author}

Lukasz Tomczyk completed a PhDr. in Adult Education at Charles University in Prague, Czech Republic, and a Ph.D. in Media Education and Social Pedagogy at Pedagogical University of Cracow, Poland. He has authored 6 monographs and 130 scientific articles and is an editor of 13 collective monographs. He has been involved as a researcher in a few international projects. Dr. Tomczyk is a member of the Academic Association of Andragogy and lectures at several universities (in Poland, Czechia, Slovakia, Macedonia, Bosnia and Herzegovina, Germany, Croatia, Brasil, and Republic of Dominica). He is a member of research networks; EU KIDS Online and COST Action CA16207 European Network for Problematic Usage of the Internet. His research interests concern media education, information society and lifelong learning. He is a reviewer of textbooks from the Ministry of National Education and was a scholarship holder of the Ministry of Science and Higher Education (young scientists).

Article submitted 2020-06-27. Resubmitted 2020-07-16. Final acceptance 2020-07-17. Final version published as submitted by the authors. 